\title{
Effect of Cadmium Exposure in Polymorphisms Gene NOS3, Blood Cadmium Level, Nitric Oxide Level, Blood Pressure and Antioxidant Enzymes
}

\author{
Hernayanti $^{1, *}$, Slamet Santoso ${ }^{1}$, and Sri Lestari ${ }^{1}$ \\ ${ }^{1}$ Biology Faculty, Universitas Jenderal Soedirman, Purwokerto - Indonesia
}

\begin{abstract}
Cadmium is one of a heavy metal which widely used in human life, especially in the electroplating industry and a mixture of textile materials. Cadmium that enters the body binds to the metallothioneins protein. It can increase the formation of free radical compounds, there by inhibiting enzyme activity such as nitric oxide synthase 3 . This gene regulates the expression of endothelial nitric oxide synthase which produce a nitric oxide. Nitric oxide role in regulated blood pressure as vasodilator with Angiotensin II as vasoconstriction. The susceptibility to $\mathrm{Cd}$ exposure will elevate if the polymorphisms of gene is found in population. The aim of this research was to know effect of cadmium to gene NOS3 polymorphisms on NO, systolic and diastolic blood pressure and antioxidant enzyme in Cd-exposed individual. The genotype individual were detected by Polymerase Chain Reaction-Restriction Fragment Length Polymorphisms (PCRRLFP) with MBo1 restriction enzyme. Parameter recorded were blood Cd, NO level, SOD, systolic and diastolic. Data were analyzed by independent t-test. These result showed that $20 \%$ of 40 individual of cases subject were detected as polymorphisms individual of NOS3gene, with GA genotype. Their fragment DNA located on $206 \mathrm{bp}, 119 \mathrm{bp}$ and $87 \mathrm{bp}$, but non polymorphisms of NO gene is only located on $206 \mathrm{bp}$. The result show cadmium could influence polymorphisms NOS3gene and decrease NO production followed by increasing of blood pressure both systolic and diastolic. Cadmium also decrease antioxidant enzyme SOD and GPx level.
\end{abstract}

Keywords:Cadmium;systolic;diastolic; SOD;GPx

\section{Background}

Cadmium is a heavy metal which is belongs to class II B in the periodic system. This metal will readily react with ligands containing elements of $\mathrm{O}$, $\mathrm{S}$ and $\mathrm{N}$. In the body Cadmium is toxic agent, because it reacts with ligands that are essential for normal body function. In living cells there are various ligands, such as: $\mathrm{OH},-\mathrm{COO}-,-\mathrm{OPO}_{3} \mathrm{H}-,-\mathrm{C}$ $=\mathrm{O},-\mathrm{SH},-\mathrm{S}-\mathrm{S}-,-\mathrm{NH}_{2}$ and $\mathrm{NH}$ which can form complex bonds with metals such as Cadmium. $\mathrm{Cd}$ exposure also causes increased free radicals in the body and causes oxidative stress characterized by decreased levels of Super Oxide dismutase (SOD) and Glutathione peroxidase (GPx) [1-2]. Cadmium in the body accumulates in the kidneys and the liver mainly binds to metallothionein. The interaction between $\mathrm{Cd}$ and metallothionein, will inhibit enzymes activity and one of them is endothelial enzyme Nitric Oxide Synthase (eNOS) [3]. The enzyme eNOS is an enzyme that produces nitric oxide $(\mathrm{NO})$ which functions in the regulation of blood pressure. The inhibition of eNOS activity cause the production of Nitric Oxide decreases result in decreasing elasticity of blood vessels. This will lead to increase vascular angiotensin II activity resulting in continuous vasoconstriction of blood vessels. This event causes elevated blood pressure called hypertension $[4,5]$. Association of blood cadmium with hypertension found in the Korean general population $[6,5]$.

The susceptibility of exposure heavy metals in human will increase when gene polymorphisms are present [7]. Chuanget al. (2006) states that gene polymorphism is an important factor affecting human susceptibility to the toxic substances such as Cd. Polymorphisms at DNA level can cause decrease in enzyme activity by $20-30 \%$. Nitric oxide synthase 3 gene polymorphism (G894T) is found in exon 7, which converts glutamate amino acid into asparagine at the position of amino acid 298 [8]. G894T polymorphism causes eNOS enzyme activity to decrease, resulting in reduced NO production. Hernayanti et al., 2012 found that $\mathrm{NOS}_{3}$ polymorphisms in carrier polymorphism $\mathrm{NOS}_{3}$ gene individuals had lower NO levels in individuals without NOS3 gene polymorphism. Low NO levels will actívate the matrix of metalloproteinase-9 and pro-inflammatory cytokines (Tumor Necrosis Factor $\alpha$ ) and increased Matrix Metalloprotein-9 (MMP-9) but decreased their inhibitor namely Tissue Inhibitor Metallo Proteinase (TIMP), so hypertension develops into aterosclerosis [9-10]. Welding workshop workers are one group of individuals who are at risk of exposure to $\mathrm{Cd}$ and are at risk of developing hypertension, especially for individuals

*Corresponding author: hernayantioentoro@ymail.com 
carrying NOS3 gene polymorphism. Early detection of hypertensive events due to $\mathrm{Cd}$ exposure, especially on the carrier of NOS3 gene polymorphism, through NOS3 molecular analysis and NO, SOD and GPx levels, systolic and diastolic blood pressure can help prevent early prevention of hypertensive disease from atherosclerosis.

Research by early detection of cadmium pollution, especially from the welding process, one of the source of cadmium exposure will contribute to reduce carbon emissions in the community. In welding process in addition to the $\mathrm{Cd}$ particles, carbon monoxide (CO) gas is also produced. $\mathrm{CO}$ gas is one of the pollutants in the air resulting from incomplete carbon combustion in gasoline.This will cause carbon emissions in the air to increase. Reduction of carbon emissions due to $\mathrm{Cd}$ and $\mathrm{CO}$ in the air means supporting a low-carbon program in community development so that people live more prosperously

\section{Material and Method Research Design}

The research design used an observational analytical design with cross sectional approach [11]. The research was conducted from June to September 2016 and the research located in welding workshop Purwokerto and Sokaraja. Target population is welding labores, while the population is affordable in this study are workshop workers in Purwokerto and surrounding areas amounted to 40 people. Sample size due to population less than 100 people, then all eligible populations of inclusion and exclusion criteria were studied. Inclusion criteria: respondents who were willing to sign Informed Consent, were not taking hypertension drugs and exclusion criteria were respondents who were taking hypertension drugs and respondents who not present at the time of the research. The independent variable is a $\mathrm{Cd}$ exposure. The dependent variables are the change $\mathrm{Cd}$ level in blood as well as changes in systolic blood pressure and diastolic welding laborers. The parameters observed were systolic and diastolic blood pressure, Cd blood level, NO level, SOD and GPx activities.

\section{Determinationof Cd level}

Respondents were taken blood in the vein section of mediana cubiti with the syringe of $5 \mathrm{~mL}$. 5 $\mathrm{ml}$ of blood is divided into 3 parts, $3 \mathrm{~mL}$ for DNA isolation, $2 \mathrm{~mL}$ for $\mathrm{Cd}$ and $\mathrm{NO}$ examination. Cadmium level detected using ACGIH method with AAS machine at wavelength $228.6 \mathrm{~nm}$ and strong currents of $3.5 \mathrm{~mA}^{0}$.

\section{Isolationof DNA}

Isolation of DNA are performed with Guanidin method. (Hingorani,1999). Erithrocyte in blood sampel is lysed using lysing buffer. Then placed in refrigerator for 20 minutes and centrifuse $750 \mathrm{~g}$ at $8000 \mathrm{rpm}$ for 10 minutes. The sampel was preparation with Guanidin, SE buffer, chloroform, $\mathrm{NaCl} 4 \mathrm{M}$ and isopropanol and stored at $40^{\circ} \mathrm{C}$.

\section{Determinationof polymorphism NOS3 gene}

Amplification gene with PCR (Hingorani et al., 1999). Forward primer : 5'-CAT GAG CGT CAG CCC CAG AAC-3' and Reverse primer : 5'-AGT CAA TCC CTT TGG TGC TCA C-3', result product located at $206 \mathrm{bp}$. PCR conditions include a 5-minute denaturation of $94^{\circ} \mathrm{C}, 35$ cycles consisting of $94^{\circ} \mathrm{C}$ denaturation 1 minute, annealing $60^{\circ} \mathrm{C} 1$ minute, elongation $72^{\circ} \mathrm{C} 1$ minute and final elongation $72^{\circ} \mathrm{C}$, 7 minutes. PCR product was digested by MboI endonuclease restriction enzyme. The results of the digestion were analyzed by electrophoresis using agarose gel and visualized with etidium bromide under UV light. The electrophoresis result were : GG was not cut off, TT was cut into2 fragments along119and $87 \mathrm{bp}$, GA into 3 fragments along 206 bp, $119 \mathrm{bp}$ and $87 \mathrm{bp}$.

\section{Determinationof Nitric Oxide level}

Determination of Nitric Oxide level by Griess Method [12]. Measured simple absorbance value at wavelength 520-560 $\mathrm{nm}$ with microplate reader. Created regression curve Y: NO standard and X: NO concentration. Made the correlation regression curve based on the concentration of standard solution. Measurement of blood pressure by digital
tensimete requipment

Installed this instrument approximately $2 \mathrm{~cm}$ below the left hand, then tightened. Th tensimeter is turned on by pressing the on button. After 2 minutes exit the numbe indicates systolic pressure (uppernumber) and diastolic pressure (bottom number). The Reading results are expressed with mmHg units.

Determinationof SOD activityusingRanSOD [13]

Sample of SOD read on spectrophotometer with wavelength $505 \mathrm{~nm}$. Standard curve graphs are created to determine SOD activity and results are expressed in U/L.

\section{Determinationof GPx activity}

Determination of GPx activity [14]. Sample wereread on Elisa Reader with wavelength $450 \mathrm{~nm}$. Standard curve graphs are created to determine GPx activity and results are expressed in $\mathrm{pg} / \mathrm{mL}$ units.

\section{Dataanalysis}

The molecular analysis of NOS3 gene polymorphism was analyzed descriptively, after the digestion results were visualized with ethidium bromide under UV light. Meanwhile, to know the effect of $\mathrm{NOS}_{3}$ gene polymorphism on blood $\mathrm{Cd}$, NO level, GPx and SOD activity using Chi square test.

\section{Result and Disccusion}

The results of NOS3 gene analysis of 40 casesubjects after digestion with MBo1 enzyme were found that 8 individuals with NOS3 polymorphism or about $20 \% \quad \mathrm{NOS}_{3}$ genepolymorphism with GA genotype, while 32 or $80 \%$ were found without polymorphism with GG genotype. Individual DNA bands with polymorphism are cut into 3 fragments 
along $206 \mathrm{bp}, 119 \mathrm{bp}$ and $87 \mathrm{bp}$ (heterozygote mutants), whereas without polymorphism lies at 206 bp (10) (Figure 1).

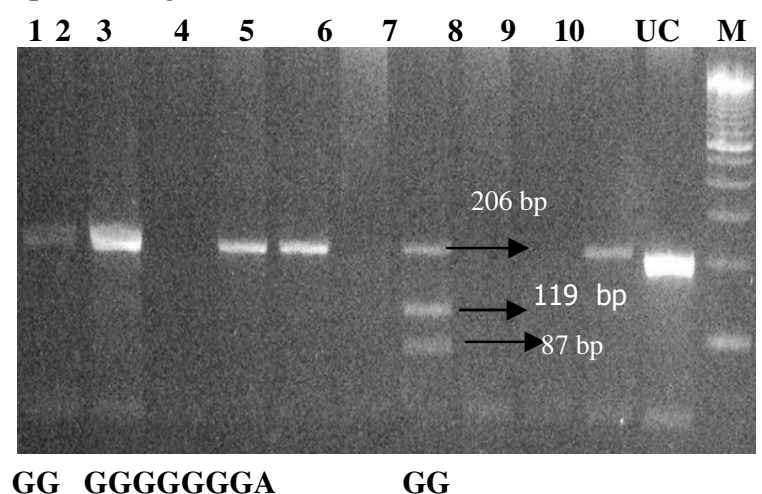

Figure1. Gene that codes NOS3 digested by restriction MBO1 enzyme on case subjects. No1,2,4,5,10 (GG) = Genotype individual without polymorphism NOS3. DNA brand not digesting lies at $206 \mathrm{bp}$ No7 (GA) = Genotype individual with polymorphism NOS3 gene. DNA brand cutting to 3 fragment lies at $206 \mathrm{bp}, 119 \mathrm{bp}$ and $87 \mathrm{bp}$.

The result of measurement of blood Cd level from 40 worker of welding labores ranged from $0,2-$ $2,32 \mathrm{ppm}$ with the mean level equal to $0,86 \pm 0,65$ ppm (normal threshold value $<0,1 \mathrm{ppm}$ ).In individual carriers of NOS3 gene polymorphisms, blood levels of $\mathrm{Cd}$ were found to be higher than nonpolymorphic individuals. Average $\mathrm{Cd}$ level in individuals with NOS3 gene polymorphism was found to be $2.06 \pm 0.143 \mathrm{ppm}$, whereas in non polymorphic individuals it was found to be lower at $0.56 \pm 0.24 \mathrm{ppm}$. Increased blood levels of $\mathrm{Cd}$ occur both in individual carriers of NOS3 gene polymorphism as well as in non-polymorphic individuals.

The result of statistical test of systolic blood pressure on individual carrier of NOS3 gene polymorphism is significant different compare with non polymorphism individual $(\mathrm{t}$ count $=4.35$ and $\mathrm{t}$ table $\alpha 1 \%=2,704)$. Individual systolic pressure of NOS3 polymorphism carrier is higher than non polymorphism individual that is $157,75 \pm 3,42$ $\mathrm{mmHg}$, whereas non polymorphism individual is $139,69 \pm 11,32 \mathrm{mmHg}$.

The result of statistical test of diastolic blood pressure also showed very significant difference between individual carrier polymorphism with non polymorphism individual ( $\mathrm{t}$ count $=4.93$ and $\mathrm{t}$ table $=\alpha 1 \%=2,704)$. Individual diastolic blood pressure of polymorphism carrier is higher that is $95,37 \pm 7.89$ $\mathrm{mmHg}$ while non polymorphism individual is 85,12 $\pm 4,17 \mathrm{mmHg}$. The mechanism of hypertension to $\mathrm{Cd}$ exposure is due to the cadmium that enters the body following blood circulation and is circulated throughout the body by bonding with the amino acid metallothionein (Mt) to form $\mathrm{Cd}+\mathrm{Mt}$ (cadmium + metallothionein) complex. The $\mathrm{Cd}+\mathrm{Mt}$ bond is stable and will inhibit the endothelial activity of nitric oxide synthase (eNOS). The inhibition of eNOS activity cause the production of Nitric Oxide decrease result in decreasing elasticity of blood vessels. This leads to increase vascular angiotensin II activity, resulting in continuously vasoconstriction of blood vessels. These events cause elevated blood pressure or hypertension (4-5) 2 times from normal will decrease NO levels by $5 \%$ and increase systolic blood pressure by $0.75 \mathrm{mmHg}$ and diastolic by 1.077 mmHg [15]

Based on the grouping of hypertension category, the result of group normotension 3 people $(7,5 \%)$, group of pre hypertension 9 people $(22,5 \%)$, group of hypertension level 1 counted 22 people $(55 \%)$ and group of hypertension level 2 counted 6 people $(15 \%)$. Individual carriers of NOS3 gene polymorphisms with grade 2 hypertension were 5 (20\%) while those with hypertension level 1 were 3 (7.5\%). In non polymorphism group, the result of group of normotensi 3 people $(7,5 \%)$, group of pre hypertension 9 people $(22,5 \%)$, group of hypertension level 1 were 17 people $(42,5 \%)$ and found no group of hypertension level 2.

The results of statistical tests of NO levels in individual carriers of $\mathrm{NOS}_{3}$ gene polymorphism differed significantly with individuals without polymorphism ( $\mathrm{t}$ count $=-5.28$ and $\mathrm{t}$ table $\alpha 1 \%=$ 2.704). Nitric oxide concentration in individual carrier of NOS3 gene polymorphism was lower than non polymorphism of $27.4 \pm 1.76 \mu \mathrm{mol} / \mathrm{L}$, whereas in non polymorphism individuals were $37.85 \pm 5.39$ $\mu \mathrm{mol} / \mathrm{L}$.

$\mathrm{Cd}$ exposure in individual carriers of NOS3 gene polymorphism is more severe hypertension than that of non-polymorphism individuals. This is in accordance with the opinion of Chuang et al., 2006 which states that a person's susceptibility to exposure to toxic compounds will increase when a gene polymorphism is found, as it will cause a $20 \%-30 \%$ decrease in enzyme function, compared to individuals without gene polymorphism.

The result of statistical test of SOD level showed very significant difference between individual carrier of $\mathrm{NOS}_{3}$ gene polymorphism with non polymorphism individual $(\mathrm{t}$ count $=4.24$ and $\mathrm{t}$ table $\alpha 1 \%=2,704)$. SOD levels in individual carriers of the NOS3 gene polymorphism were lower at $112.87 \pm 4.72 \mathrm{U} / \mathrm{L}$ compared with non polymorphic individuals with SOD levels of $137.85 \pm 5.39 \mathrm{U} / \mathrm{L}$.

$\mathrm{Cd}$ bonds with methallotionein in the liver and kidneys increase the production of free radicals in the body such as superoxide anions, hydroxyl radicals and hydrogen peroxide. These free radicals will lead to lipid peroxidation reaction that characterized by the elevated of mallondialdehyde (MDA) level and cause oxydative stress characterized by decreasing activity of the antioxidant enzymes SOD, GPx and catalase [16].

The function of SOD is to capture $\mathrm{O}_{2}^{-}$and convertit to hydrogen peroxide $\left(\mathrm{H}_{2} \mathrm{O}_{2}\right)$. But if $\mathrm{O}_{2}^{-}$ formation is excessive, SOD are not able to neutralize $\mathrm{O}_{2}{ }^{-}$and convert into $\mathrm{H}_{2} \mathrm{O}_{2}$. The SOD enzyme located in the cytoplasme and extracellular require ion co- 
factors $\mathrm{Cu}$ and $\mathrm{Zn}$,whereas SOD located in mitochondrial requires the $\mathrm{Mn}$ co-factor. Cadmium is antagonistic to the metal ion cofactors. Cadmium will substitute the $\mathrm{Cu}, \mathrm{Zn}$ and $\mathrm{Mn}$, on the other hand the function of these metals are to arrange SOD, so that the SOD enzymes in the cytoplasme, extracellular fluid and mitochondrial become inactive [17-18].

The result of statistical analysis for GPX activity showed a very significant difference between individual carrier of NOS3 gene polymorphism compared with non polymorphism individual ( $t$ count $=8.46$ and $\mathrm{t}$ table $\alpha 1 \%=2,704)$. GPx activity in individual carriers of NOS3 gene polymorphism was lower at $45.33 \pm 3.57 \mu \mathrm{mol} / \mathrm{L}$, whereas the individuals with polymorphisms were GPx activity were $92.62 \pm 15.33 \mu \mathrm{mol} / \mathrm{L}$.

Cadmium could substitute Selenium (Se) which is a cofactor for GPxactivity, so the GPx enzyme becomes inactive. The GPx function is to continue the SOD function to convert $\mathrm{H}_{2} \mathrm{O}_{2}$ to $\mathrm{H}_{2} \mathrm{O}$ and $\mathrm{O}_{2}$. As a result there is accumulation of free radicals of $\mathrm{O}_{2}^{-}$and $\mathrm{H}_{2} \mathrm{O}_{2}$. $\mathrm{Cd}$ bonds with methallotionein on the liver and kidneys will decrease glutathione levels that are substrates for GPx. Glutathione also functions in the body's antioxidant defenses. Lack of glutathione production will cause damage to the liver and kidneys getting worse and will increase the toxicity of Cd (Johri, et al, 2010).

\section{Conclusion}

This result show that the exposure of $\mathrm{Cd}$ influence in NOS3gene. Polymorphism of NOS3gene in welding labour wasfound $20 \%$ and in non polymorphismindividual $80 \%$. Cd level, systolic and diastolicblood pressure in individualwithNOS3genepolymorphismishigher.

And they have NO, SOD and GPx levels are lower than that of non polymorphism individual. The incidence of hypertension in individual carriers of NOS3genepolymorphismsisfound as many as 5 people (20\%)with hypertension level 2, while 3 people $(7.5 \%$ )with hypertension level 1 . In non polymorphism individuals is found normotension 3 people $(7.5 \%)$, pre hypertension 9 people $(22.5 \%)$, hypertension level 1 as many as 17 people (42.5\%) and hypertension level 2 is not found.

\section{Ackowledgement}

On this occasion, wethank the Ministry of Research, Technology and Higher Education through the SteeringCommittee of Research and Community Service Institute of the University of JenderalSoedirman, for the FundamentalFundsFund for Fiscal Year 2016 and Reseach of Institutional BLU Fund for Fiscal Year 2017, sothisresearchcanbesolved.

\section{References}

1. Satarug, S. Nishijo, M., Lasher J.M. Edward R.J. and M.C Moore Tohoku. J. Exp. Med, 208,3 (2006).

2. Widowati, W., A. Sastiono dan R.J. Rumampuk, Efek toksik logam pencegahan dan penanggulangan pencemaran (2008).

3. Johnson, D. W., R.D.J Graham., H.M Timothy., J.L. Marie., P.D. Matthew and P.D. Matthew, Medical. J.ofAustralia, 197, 4(2012).

4. Gallagher, C.M and J.R. Meliker.Environ. Health.Perspect. 118,112 (2010)

5. Caciari, T., A. Sancini., M. Fioravanti., A.Cappozella., T. Casale. Int. J. Occup Med. Environ.H. 26, 3 (2013).

6. Lee, B.K and J. Kim, Am. J. In Med. 55,11 (2012).

7. Chuang, H.J.,Yu, K.T., Ho, C.K., Wu, M.T., Lin, G.T. dan Wu, T.N. J. OccupHealth 46 (2006)

8. Hingorani D.A., C.F. Liang., J. Fatibene., A.Lyon.., S. Monteith., A., Parsons, S. Haydock., R.V. Hooper., N.G. Stephens., K.M. Osaughnessy and M.J. Brown,Circulation10,5(1999).

9. Hernayanti, Sukarti, M., Sadewa A.H., Hariono, B., and Wahyuono, S,J.Manusia dan Lingkungan19,2(2012).

10. Santoso and Hernayanti. Efek polimorfisme gena nitrit oksida sintase3(NOS3) terhadap kejadian hipertensi pada individu terpapar Plumbum.Laporan Penelitian Fundamental DIKTI (2016).

11. Joshi, M.S., C. Mineo, P.W. Shaul and J.A. Baurer.The Faseb.J.219 (2007).

12. Sastroasmoro, S., Ismail, S.Dasar-Dasar Metodologi Penelitian Klinis,(2011)

13. Sungdaewon.D, K.J. Sungnam and D. Kyungki,Nitric oxide detection kit. Korea : Intron Biotechnology, Inc.(2002).

14. RandoxLaboratories.Manual procedure RanSOD (2009)

15. Thermo Fisher Scientific, Inc Glutathion Peroxidase kit. Pierce Biotechnology (2010).

16. Camila, C. Almenara. Gilson, B. Broseghini, F. Marcus, V. Vescoviet al. Chronic cadmium treatmentpromotesoxidative stress and endothelial damage in isolated rat aorta. Plos One. 8 (2013)

17. Bernhoft, R.A. Cadmium toxicity and treatment. The Scientific World Journal13,1(2013).

18. Messner, B and D. Bernhard, Biometals23, 5 (2010).

19.Johri, N., J. Gregory and U. Robert, Biometals 23 (2010). 